PERM JOURNAL OF PETROLEUM AND MINING ENGINEERING

ВЕСТНИК ПНИІУ. ГЕОЛОГИЯ. НЕФТЕААЗОВОЕ И ГОРНОЕ ДЕЈЮ

ISSN 2224-9923

Volume/ Tом 18 №1, 2018

http://vestnik,pstu.ru/geo/

УДК 622.276.43:[622.8+614.8]

Article / Статья

(c) PNRPU / ПНИПУ, 2018

\title{
ASPECTS OF ENVIRONMENTAL AND INDUSTRIAL SAFETY OF NON-AQUEOUS PROCESS FLUIDS IN CONSTRUCTION AND COMPLETION OF WELLS
}

\section{Irina L. Nekrasova}

PermNIPIneft branch of LUKOIL-Engineering LLC in Perm

(29 Sovetskoy Armii st., Perm, 614066, Russian Federation)

\section{АСПЕКТЫ ЭКОЛОГИЧЕСКОЙ И ПРОМЫШЛЕННОЙ БЕЗОПАСНОСТИ ПРИМЕНЕНИЯ ТЕХНОЛОГИЧЕСКИХ ЖИДКОСТЕЙ НА НЕВОДНОЙ ОСНОВЕ В ПРОЦЕССАХ СТРОИТЕЛЬСТВА И ОСВОЕНИЯ СКВАЖИН}

\author{
И.Л. Некрасова \\ Филиал ООО «ЛУКОЙЛ-Инжиниринг» «ПермНИПИнефть» в г. Перми \\ (614066, Россия, г. Пермь, ул. Советской Армии, 29)
}

Received / Получена: 17.04.2018. Accepted / Принята: 01.09.2018. Published / Опубликована: 28.09.2018

\section{Key words:}

non-aqueous process fluids, invert-emulsion drilling muds, olefins, paraffins, biodegradation degree, hazard class, toxic effects on ecosystems, flash point.

\section{Ключевые слова:}

технологические жидкости на неводной основе, инвертноэмульсионные буровые растворы, олефины, парафины, степень биодеградации, класс опасности, токсическое воздействие на экосистемы, температура вспышки.

\begin{abstract}
Nowdays, reserves complex in terms of geology, pressure and temperature are involved into production. That is accompanied by the increase in use of non-aqueous process fluids, especially invert-emulsion drilling muds. One of the key problems that are an obstacle for mass application of non-aqueous fluids in construction and completion of wells is a high man-made effect on the environment due to their environmental hazard and need to ensure enhanced industrial safety measures when used in field conditions. The classification of dispersion media used in modern non-aqueous process liquid formulations is proposed. The following indicators of "environmental friendliness" and industrial safety of this type of liquids are considered: toxic effects on ecosystems, ability to degrade in the natural environment to safe products under the influence of microorganisms, indicators of industrial sanitation and fire safety. The factors affecting the flash point temperature of non-aqueous process fluids were analyzed. Stricter requirements for environmental readings of the dispersion medium of process fluids on a non-aqueous basis will improve the environmental situation in areas of drilling operations. Knowing the basics of management of fire-hazardous properties of this type of liquids will increase the industrial safety of their use in field conditions. The aspects of environmental and industrial safety of process fluids on a non-water basis, presented in the paper, will be useful for specialists in the field of drilling and production who are engaged in design and development of process fluids, including shale oil and gas deposits.
\end{abstract}

В настоящее время в процессах строительства и освоения нефтегазовых скважин в связи с вовлечением в разработку месторождений со сложными геологическими и термобарическими условиями наметилась отчетливая тенденция роста объемов использования технологических жидкостей на неводной основе, в особенности инвертноэмульсионных буровых растворов. Одной из ключевых проблем, являющихся препятствием для массового внедрения жидкостей на неводной основе в процессы строительства и освоения скважин, является высокая техногенная нагрузка на окружающую природную среду вследствие их экологической опасности, а также необходимость обеспечения повышенных мер промышленной безопасности при их применении в промысловых условиях. Предложена классификация дисперсионных сред, используемых в современных рецептурах технологических жидкостей на неводной основе. Рассмотрены следующие показатели экологичности и промышленной безопасности данного типа жидкостей: токсическое воздействие на экосистемы, способность к деградации в природной среде до безопасных продуктов под воздействием деятельности микроорганизмов, показатели промышленной санитарии и пожаробезопасности. Исследованы факторы, влияющие на значение температуры вспышки технологических жидкостей на неводной основе. Ужесточение требований в отношении экологических показателей дисперсионной среды технологических жидкостей на неводной основе позволит улучшить экологическую ситуацию в районах ведения буровых работ. Знание основ управления пожароопасными свойствами данного типа жидкостей позволит повысить промышленную безопасность их применения в промысловых условиях. Представленные в статье аспекты экологической и промышленной безопасности технологических жидкостей на неводной основе будут полезны специалистам в области бурения и добычи, занимающимся проектированием и разработкой технологических жидкостей, в том числе для сланцевых месторождений нефти и газа.

Irina L. Nekrasova - PhD in Engineering, Leading Research Fellow at the Department of Drilling Muds and Process Fluids (tel.: +007 342 233 67 63, e-mail: Irina.Nekrasova@pnn.lukoil.com).

Некрасова Ирина Леонидовна - кандидат технических наук, ведущий научный сотрудник отдела буровых растворов и технологических жидкостей (тел.: +007 34223367 63, e-mail: Irina.Nekrasova@pnn.lukoil.com). 


\section{Introduction}

Nowdays, reserves complex in terms of geology, pressure and temperature are involved into production. That is accompanied by the increase in use of non-aqueous process fluids, especially invert-emulsion drilling muds. Currently, all leading foreign and domestic service companies have this type of drilling mud [1]. Due to the ability to preserve natural reservoir properties non-aqueous process fluids are also widely used as killing, completion and perforation fluids [2, 3]. The main advantage of using this type of killing fluids and perforation is to prevent swelling and dispersion of formation rocks composed of clay minerals. [4].

One of the key problems that are an obstacle for mass application of non-aqueous fluids in construction and completion of wells is a high man-made effect on the environment due to their environmental hazard and need to ensure enhanced industrial safety measures when used in field conditions.

Unit recently natural hydrocarbon liquids such as oil and gas condensates and oil refining products (kerosene, gas oil, and diesel fuel) have been used as the most common dispersion medium for non-aqueous emulsion drilling fluid (NAEDF) tested in practice [5-7]. Availability and relatively low price were the main features for them to be used as a dispersion medium of non-aqueous process fluids. Oil and its products contain compounds that are additional natural stabilizers and emulsifiers for inverse emulsions in terms of their properties. Therefore, obtaining highly stable structured solutions on their basis is a fairly simple technological task. These compounds mainly belong to the group of aromatic, oxygencontaining and sulfur compounds (resins, asphaltenes). At the same time, it is aromatic compounds that determine the high toxicity of hydrocarbon-based solutions [8]. According to the degree of harmful effects on ecosystems, oil and oil products rank second after radioactive contamination [9].

\section{Classification of dispersion media of process liquids}

In recent years, due to the fact that environmental requirements have become tightened, it is necessary to replace traditional hydrocarbon liquids (oil, diesel fuel) with more environmentally friendly fireproof biodegradable hydrophobic fluids while retaining all the advantages of emulsion drilling fluids. Currently, the development of fire and environmentally hazardous NAEDF modifications goes in several directions. The following products are used as the basis of invert emulsions [10-15]:

- refined and less toxic mineral oils that do not contain high concentrations of mono- and polyaromatic hydrocarbons that are toxic to biota;

- isolated from the mixture of hydrocarbons separate fractions (mainly paraffin-naphthenic), subjected to biodegradation;

- products based on vegetable raw materials.

The classification of dispersion media used in modern NAEDF formulations [16] is shown in Fig. 1

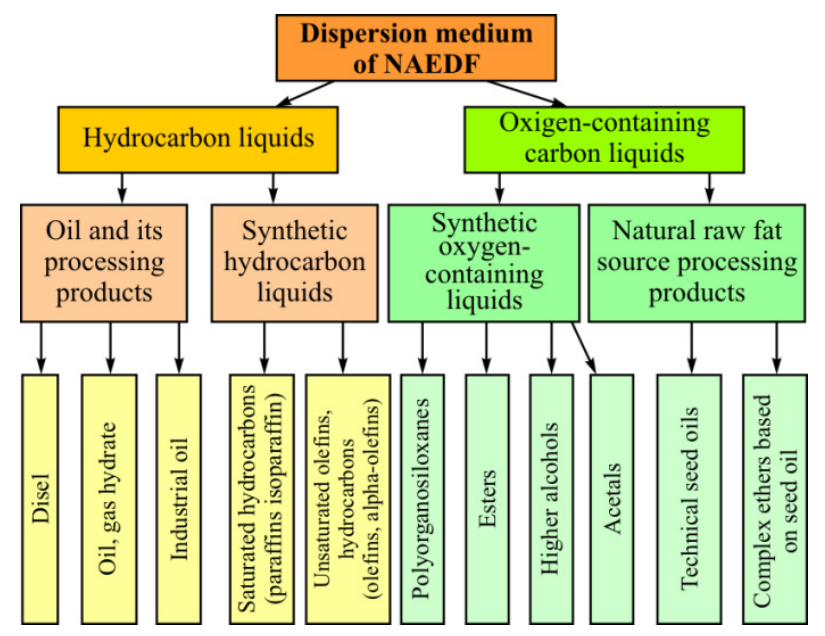

Fig. 1. The classification of dispersion media NAEDM 
Synthetic oils used to prepare non-aqueous process fluids [22-24]

\begin{tabular}{|c|c|c|}
\hline Tradename & Synthetic base solution & Manufacturer \\
\hline ISO-TEQ & Olefins (mixture $\mathrm{C}_{14}-\mathrm{C}_{20}$ ) & Baker Hughes INTEQ \\
\hline NX-3500 & Ester & Baker Hughes INTEQ \\
\hline BG-550 & Ester & Baker Hughes INTEQ \\
\hline PT-3500 & Isoparaffin & Baker Hughes INTEQ \\
\hline ALPHA-TEQ & Linear alpha olefins (mixture $\mathrm{C}_{14}-\mathrm{C}_{16}$ ) & Baker Hughes INTEQ \\
\hline NOVAPLUS & Olefins (mixture $\mathrm{C}_{16}-\mathrm{C}_{18}$ ) & Schlumberger \\
\hline ECOGREEN & Ester & Schlumberger \\
\hline NOVATEC & Linear alpha olefins (mixture $\mathrm{C}_{14}-\mathrm{C}_{18}$ ) & Schlumberger \\
\hline PARADRIL & Paraffin & Schlumberger \\
\hline PETROFREE SF & Olefins (mixture $\mathrm{C}_{16}-\mathrm{C}_{18}$ ) & Baroid \\
\hline PETROFREE & Ester & Baroid \\
\hline PETROFREE LE & Linear alpha olefins (mixture $\mathrm{C}_{14}-\mathrm{C}_{18}$ ) & Baroid \\
\hline XP-07 & Linear Paraffin & Baroid \\
\hline
\end{tabular}

Application of ethers, polyorganosiloxanes, polyalkylene glycols, polyalphaolefins is considered in many silutions of the modern process fluids [17-21]. Operators engaged in offshore drilling back in the 1980s last century began research to create synthetic-based drilling muds that minimize damage to the marine environment. In 1993, a well was drilled in the North Sea using M-I Drilling Fluids based on polyalphaolefins, hydrocarbons with a chain length of about 10-12 atoms [18]. Types of synthetic fluids used in the formulations of leading foreign companies are given in Table 1. Application of synthetic oils reduces the load on the environment, expands the possibilities of using oils, including as the basis of emulsion drilling fluids, in conditions of both negative and high temperatures. However, the high cost and narrowness of the domestic range of synthetic oils limit their use in drilling technologies.

Vegetable oils (peanut, soybean, linseed, corn, castor etc.) and their products are ones of the most ecologically safe organic substances [25-29]. The basis of vegetable oil is esters (triglycerides) of high-molecular saturated and unsaturated carboxylic acids. The advantage of vegetable oils is their almost complete biodegradation under aerobic and anaerobic conditions. The lack of invert solutions based on organic liquids of plant origin is the complexity of their preparation and regulation of technological parameters, due to the variability of the composition and properties of plant materials for the production of oils, high viscosity and pour point of the original oils.

\section{Indicators of environmental safety of non-aqueous process fluids}

Environmental friendliness and industrial safety of non-aqueous process fluids can be assessed by the following indicators:

- toxic effects on ecosystems,

- the ability to degrade in the natural environment to safe products under the influence of the activity of microorganisms,

- indicators of industrial sanitation and fire safety.

According to ASTM, toxicity of organic liquids is estimated by the toxicity of their aqueous extracts using various biotesting methods, one of which is 25 for diesel fuel, 11.5 for acetal, 4 for alpha-olefin, 1.6 for coriander oil, and polyalphaolefins for zero [30]. Results of a large number of experiments conducted by the European Center for Ecotoxicology and Toxicology of Chemicals showed that the action of anaerobic bacteria in different liquids is not the same. Biodegradation was found to be very high in fatty acids and essential oils. At the same time, in mineral oils, diethyl ether, polyalphaolefins and a number of other compounds, biodegradation was absent or only partially occurred [31]. In our country, in accordance with the "Criteria for classifying waste as hazardous for the environment" [32] for liquid waste, including 
NAEDM, no water extracts are made, and the viability of hydrobionts in the environment of the waste itself is checked (i.e. oils). The calculated method of determining the hazard class for the environment is applicable only to waste of I-IV classes, since it is obligatory to conduct biotesting of the studied waste for class V. Due to the fact that hydrobionts cannot develop normally in an oily environment without access of dissolved oxygen, the assignment of any organic liquid to the $\mathrm{V}$ class of hazard by the method of biotesting is impossible.

Many developers of non-aqueous process fluids estimate the environmental safety of oils by the degree of their biodegradation. In special reviews [33-36], it is reported that almost all hydrocarbons to some extent undergo microbiological oxidation. For example, light petroleum products such as diesel fuel at an initial concentration in the soil of $0.5 \%$ in 1.5 months degrade by $10-80 \%$ of the initial amount depending on the content of volatile hydrocarbons. The degree of biodegradation of unsaturated aliphatic hydrocarbons (olefins and alpha-olefins) in aerobic conditions exceeds $70 \%$, in anaerobic conditions - $53 \%$ [37]. Aromatic hydrocarbons have the highest resistance to microbiological oxidation. Thus, application of paraffins, which are most susceptible to microbial oxidation, and also paraffin-naphthenic fractions of oil and oils as basics of process fluids to a greater extent meet the requirements of environmental safety than the use of oil products with a high content of aromatics [10].

When assessing the ability of a liquid for biodegradation, it is necessary to take into account that microbiological oxidation occurs in the range of $18-40{ }^{\circ} \mathrm{C}$ at the optimum of $28-32{ }^{\circ} \mathrm{C}$, which eliminates the process of degradation of any hydrocarbon fluid when it enters the environment (as part of drill cuttings, leaks solution) in the winter and in areas with cold climates [38]. Due to the fact that there is almost no biodegradation in cold climate conditions, currently the legislative bodies of most developed countries, particularly in the UK and Canada during offshore drilling prohibit discharge of spent drilling muds on both hydrocarbon and synthetic basises. There is Environmental Protection Agency (EPA) in the USA that prohibits the discharge of drilling mud and sludge at a distance of three miles from the coast [39]. Synthetic-based solutions in Norway are being tested for bioaccumulation and biodegradation. Permission to dump waste into the sea is given in the case of favorable results of these tests only. While dumping synthetic-based muds north of the $62^{\text {nd }}$ parallel is prohibited at all [40].

Nowdays, the bodies of Rosprirodnadzor classify the waste that contain $15 \%$ or more of petroleum products as hazard class III substances (moderately hazardous substances). The PND F 16.1:2:2.2:2.3:3.64-10 is the main method for the determination of petroleum products in the calculation of the hazard class of waste 1 [41]. According to this method, the indicator "oil products" is taken as a mixture of non-polar organic substances contained in the waste, soluble in hexane. In addition to traditional petroleum products, this indicator includes synthetic liquids soluble in hexane, in particular polyalphaolefins and even vegetable oils. Thus, on the basis of the waste ranking adopted in our country, all non-aqueous process fluids will be classified as hazard class III. It comes that there is no reason to replace traditional hydrocarbon liquids with their environmentally safe counterparts and indicates the need to revise the methods used to determine oil products to eliminate environmentally friendly organic liquids from this indicator.

Another significant factor limiting the use of non-aqueous process fluids, especially oil, in field conditions, is their high fire safety, evaporation and toxic effects on the human body when it enters through the air passage and skin. The risk to life and health increases significantly with presence of hydrogen sulfide in oil and oil products. The negative impact of mineral oils on the human body occurs when exposed to open skin or when working in clothes soaked with them, as well as inhalation of oily fumes or mist. State-of-the-art synthetic oils on the basis of paraffins are not harmful if swallowed and do not irritate the skin and mucous membranes of a 
person. Therefore, they are preferable in terms of meeting industrial safety requirements [42]. Due to predominant use of traditional hydrocarbon products in the construction of wells, there is an urgent need to introduce a wide range of organizational and technical measures to ensure the safety of personnel working directly with this type of fluid.

\section{Investigation of factors affecting the flash point temperature of non-aqueous process fluids}

Most organic liquids used as an NAEDF dispersion medium belong to a group of flammable substances that can flash upon contact with an open source of fire. The flammable and explosive properties of organic liquids, which characterize their ability to ignite during heating and subsequent flame spread, determine the flash point. The flashpoint is the lowest temperature at which vapors above the surface of a flammable substance flash upon contact with an open source of fire [43]. There are two methods for determining the flash point of petroleum products in open (GOST 433387) and closed (GOST 6356-75) crucibles are standardized. V.N. Glushchenko notes that when controlling the NAEDF flash point, preference should be given to an open crucible. This is due to the simulation of the real conditions of use of drilling fluids in wells [44].

The greatest danger in field conditions are fluids belonging to the category of flammable, i.e. able to flash at temperatures below $61{ }^{\circ} \mathrm{C}$ in a closed crucible and below $66{ }^{\circ} \mathrm{C}$ in an open one [43]. At the same time, the main danger of using flammable liquids is related to the so-called human factor: non-compliance of safety requirements by the drilling crew when working with such liquids. In particular, when using NAEDF in the fields of the Perm region, a number of cases of flame occurrence above the surface of the hydrocarbon base NAEDF were noted at the stage of solution preparation while simultaneously carrying out welding and smoking personnel.

There are quite a few works on the correlation of the flash point of organic liquids depending on their composition. At the same time, there is almost nothing about the study of factors affecting the flash point of technological fluids on a nonaqueous basis.

It is obvious that the flash point of anhydrous process liquids corresponds to the flash point of their dispersion medium. According to our assumption, the flash point of emulsion process fluids, including NAEDF, is determined by the flash point of its dispersion medium and water content. In addition, the study the effect on the flash point of solutions of the quantitative content of insoluble solids - weighting agents (calcium carbonate and barite) in them can be of some interest.

For certain classes of hydrocarbons, empirical coefficients $a$ and $b$ are derived. The coefficients connect the flash point with their boiling point according to the following equation [45]:

$$
T_{\text {flash }}=a+b \cdot t_{\text {boil }} \text {. }
$$

Using these coefficients, we obtain the following dependence:

- for saturated hydrocarbons

$$
T_{\text {flash }}=0.693 T_{\text {boil }}-73.22 \text {; }
$$

- for aromatic hydrocarbons

$$
T_{\text {flash }}=0.665 T_{\text {boil }}-67.83 \text {. }
$$

Thus, based on the data presented for the preparation of NAEDF, it is recommended to use diesel fuels, mineral, synthetic and low-viscosity low-caking base oils (the basis of commercial oil without additional additives) containing hydrocarbon fractions with a $T_{b o i l}$ not lower than $194{ }^{\circ} \mathrm{C}$ (according to calculations is more than $61{ }^{\circ} \mathrm{C}$ ). Data on the maximum solution temperature at the wellhead is required to issue recommendations for high-temperature wells.

Due to the fact that low viscosity hydrocarbon liquids, including diesel (marine) fuel, are the most suitable for the preparation of NAEDF from an economic point of view, it becomes very important to increase their flash point. The results of studies on the possibility of increasing the flash point of flammable by introducing high-boiling hydrocarbon fractions are presented in Table 2.

Data given in Table 2 indicate that the addition of mineral oil at a concentration of $15 \%$ can increase the total fuel oil $\mathrm{T}_{\text {flash }}$ by only $4{ }^{\circ} \mathrm{C}$, while 
the kinematic viscosity of the mixture increases by 1.3 times, which leads to an undesirable increase in the rheological properties of NAEDF, especially plastic viscosity. The actual value of the flash point of a mixture of hydrocarbons is always lower than the arithmetic average temperature of the flash points of the components that make up the mixture calculated by the additivity rules. This is due to the fact that the flash point depends mainly on the vapor pressure of the low-boiling component, and the high-boiling component serves only as a heat transmitter.

Table 2

Flash point of hydrocarbon liquids of different composition

\begin{tabular}{|l|c|c|}
\hline \multicolumn{1}{|c|}{ Fluid composition } & $T_{\text {flash}}{ }^{\circ} \mathrm{C}$ & $\begin{array}{c}\text { Kinematic viscosity } \\
\text { at } 20{ }^{\circ} \mathrm{C}\end{array}$ \\
\hline Diesel fuel & 53 & 2.73 \\
\hline $\begin{array}{l}\text { Diesel fuel - 95\%, } \\
\text { base oil - 5\% }\end{array}$ & 52 & 2.90 \\
\hline $\begin{array}{l}\text { Diesel fuel - 90\%, } \\
\text { base oil - 10\% }\end{array}$ & 53 & 3.21 \\
\hline $\begin{array}{l}\text { Diesel fuel - 85 \%, } \\
\text { base oil - 15\% } \%\end{array}$ & 57 & 3.43 \\
\hline $\begin{array}{l}\text { Diesel fuel - 95 \%, } \\
\text { oil I-8 - 5\% } \%\end{array}$ & 53 & 3.03 \\
\hline $\begin{array}{l}\text { Diesel fuel - 90\%, } \\
\text { oil I-8 - } 10 \%\end{array}$ & 53 & 3.49 \\
\hline $\begin{array}{l}\text { Diesel fuel - 85 \%, } \\
\text { oil I-8 - } 15 \%\end{array}$ & 55 & 3.83 \\
\hline
\end{tabular}

Note: $T_{\text {flash }}$ of base oil $-163{ }^{\circ} \mathrm{C}, T_{\text {flash }}$ of oil I- $8-152{ }^{\circ} \mathrm{C}$, flash point was determined in a closed crucible. The matrix of mineral hydraulic oil without additional additives was used as the base oil.

The second factor determining the flash point of NAEDF is the ratio in the solution of the hydrocarbon and aqueous phases. It is considered a priori that the higher the content in the solution of the aqueous phase, the higher the flash point is. Fig. 2 presents data on the effect of water content on the value of the flash temperature of NAEDF based on diesel fuel.

The most NAEDF formulations of leading foreign companies the water-oil ratio of hydrocarbons is 80:20 and 70:30. Such the insignificant water content allows to increase the flash point of the solution by $15-20 \%$ compared to the flash point of the fuel used for its preparation. This suggests that in order to prepare
NAEDF with low water content it is recommended to use mineral oils having a high flash point.

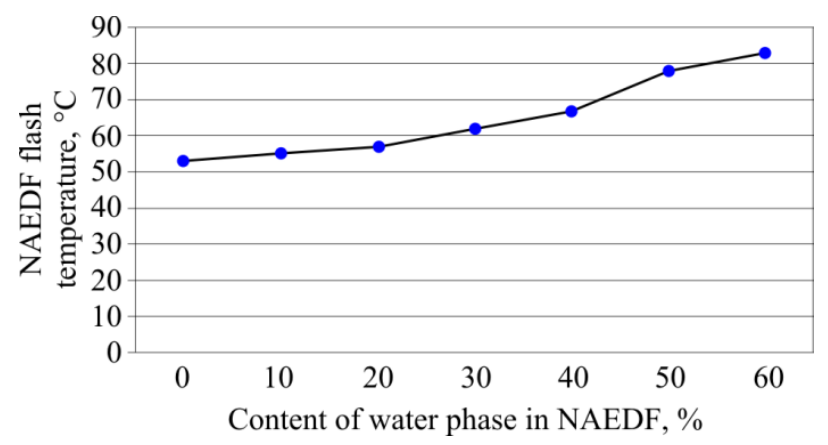

Fig. 2. The effect of the content of the aqueous phase in NAEDF on the flash point of the solution

According to the "Safety Rules in the Oil and Gas Industry" (SROGI), the flash point of a hydrocarbon-based drilling fluid must be $50{ }^{\circ} \mathrm{C}$ higher than the maximum temperature at the wellhead [46]. Thus, it becomes very important at the stage of drilling fluid design to predict the final flash temperature of NAEDF considering water content and passport value of the flash point of the oil or fuel used to prepare the solution. In order to identify statistical dependence we conducted laboratory studies to determine the flash temperature of NAEDF using diesel fuel from different producers. It is important to ensure the formulation of the solution has not changed: the content of the aqueous phase (solution of calcium chloride) was 50 vol. \%. A total of 30 NAEDF samples were prepared, and as a result of the study and statistical data processing, we obtained the following dependence (Fig. 3). Thus, knowing the passport value of the flash point of the fuel or oil, it is possible to calculate the approximate value of the NAEDF flash point, prepared on the basis of this fluid.

The second goal of the study was to built similar dependencies for NAEDF prepared on the basis of mineral and synthetic oils with a flash point of more than $100{ }^{\circ} \mathrm{C}$. The research results showed that the difference between the flash point of NAEDF and the flash point of the oil is within the measurement error; the presence of the aqueous phase does not affect the flash point of the solutions (Table 3). 


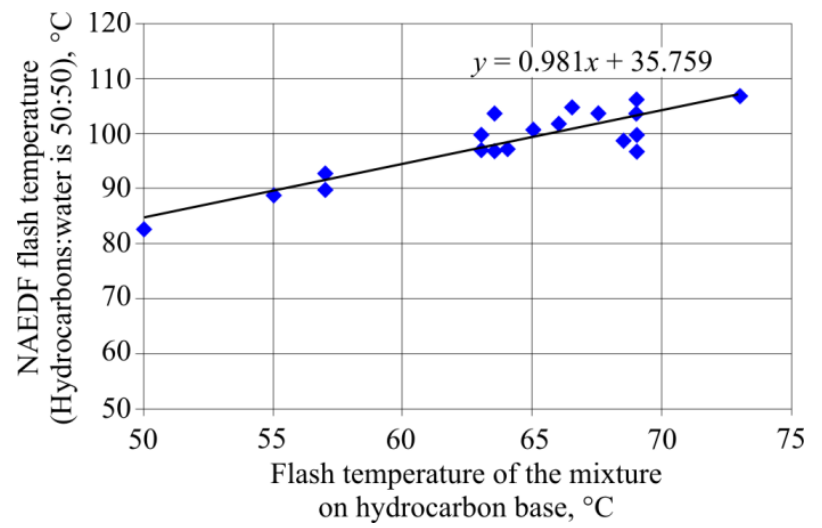

Fig. 3. Dependence of the flash temperature of NAEDF from flash point of diesel fuel

Table 3

Flash point of NAEDF, prepared on the basis of mineral oils with a flash point of more than $100^{\circ} \mathrm{C}$

\begin{tabular}{|l|c|c|}
\hline NAEDF dispersion medium & $\begin{array}{c}T_{\text {flash }} \text { of dispersion } \\
\text { medium, }{ }^{\circ} \mathrm{C}\end{array}$ & $\begin{array}{c}T_{\text {flash }} \text { of } \\
\text { NAEDF, }{ }^{\circ} \mathrm{C}\end{array}$ \\
\hline Industrial oil I-8 & 152 & 150 \\
\hline Transformer oil T-1500 U & 135 & 137 \\
\hline Base mineral oil & 163 & 170 \\
\hline Polyalphaolefins PAOM-2 & 155 & 157 \\
\hline
\end{tabular}

Note: phase ratio of NAEDF hydrocarbons:water is 50:50.

It is known from theoretical calculations that the flash point of NAEDF depends on the properties of the dispersion medium (oil), but is much higher than the flash point of the latter [47]. Therefore, having obtained such ambiguous data, we carried out repeated experiments, during which similar results were obtained. When the solutions are heated above $120-130{ }^{\circ} \mathrm{C}$ the water phase boils away completely corresponding to the flash point of the oil, only the hydrocarbon medium with solid fillers remains in the solution. It became clear only with the analysis of the method for determining the NAEDF flash point associated with heating the solution by electrical heating in an open crucible to temperatures well above the boiling point of water. This conclusion is very important when designing solutions for high-temperature wells, since it allows to predict the flash temperature of NAEDF and choose mineral and synthetic oil as the basis of the solution, the flash point of which corresponds to SROGI.

Usually, NAEDFs are a three-phase system containing weighting agents and builders as a solid phase. The content of the weighting agent in
NAEDF (barite and $\mathrm{CaCO}_{3}$ ) can reach a rather high value - up to 50-70 wt. \%, due to the need to obtain solutions with the required density. Accordingly, there is a question arised about the effect of the concentration of a solid phase in a solution on its flash point. Our studies have shown that it is not possible to regulate NAEDF flash point by changing the content in the system of the solid phase (Table 4).

Table 4

Influence of barite content on NAEDF flash point

\begin{tabular}{|c|c|c|c|}
\hline $\begin{array}{c}\text { Content of barite } \\
\text { in NAEDF, } \\
\text { mas. } \%\end{array}$ & $\begin{array}{c}\text { Content of } \\
\text { aqueous phase } \\
\text { in solution, vol. } \%\end{array}$ & $\begin{array}{c}T_{\text {flash }} \text { of } \\
\text { dispersion } \\
\text { medium, }{ }^{\circ} \mathrm{C}\end{array}$ & $\begin{array}{c}T_{\text {flash }} \\
\text { NAEDF, } \\
{ }^{\circ} \mathrm{C}\end{array}$ \\
\hline No & 50 & 63.0 & 97.0 \\
\hline 5 & 50 & 63.5 & 98.0 \\
\hline 10 & 45 & 67.0 & 100.5 \\
\hline 15 & 45 & 69.5 & 109.0 \\
\hline 20 & 40 & 73.0 & 101.0 \\
\hline 50 & 35 & 72.0 & 86.0 \\
\hline
\end{tabular}

Weighting agents presented in the solution would not increase the value of its flash point even at high concentrations. As it was mentioned above, this is due to the fact that the flash point of the solution is determined primarily by the flash point of volatile combustible components contained in the hydrocarbon-based solution, the volumetric content of which in the gas-air mixture above the surface of the solution does not depend on solid phase.

\section{Conclusion}

There is a trend that shows complication of geological conditions in well drilling. Therefore, the share of non-aqueous process fluids used in drilling will inevitably increase. Knowledge of the basics of managing the fire-hazardous properties of this type of liquids will improve the industrial safety of their use in field conditions. Making requirements stricter in terms of environmental performance of the dispersion medium of nonaqueous process fluids will improve the environmental conditions in drilling areas. The analysis of the environmental performance of various organic hydrophobic liquids indicates only relative safety and low hazard of synthetic and plant products, since the safety of these compounds can be considered and compared only 
with respect to oil and toxic products of its processing. These fluids are more fire-resistant, characterized by less evaporation and toxic effects on the human body when entering through the respiratory tract and skin. At the same time, when working with organic liquids, their discharge into objects of the natural environment is unacceptable. If an organic liquid released on the soil and water bodies, it is necessary to collect and neutralize them by special methods.

\section{References}

1. Nekrasova I.L., Garshina O.V., Khvoshchin P.A. Teoriya i praktika ispolzovaniya invertno-emulsionnykh rastvorov $\mathrm{v}$ protsesse stroitelstva skvazhin [Theory and practice of using invert-emulsion solutions in well construction]. Perm, Aster, 2016, 148 p.

2. Petrov N.A. Povyshenie kachestva zakanchivaniya skvazhin s polimiktovymi kollektorami nefti [Improving the quality of completion of wells with polymictic oil reservoirs]. Ufa, Ufimskiy gosudarstvennyy neftyanoy tekhnicheskiy universitet, 2010, $68 \mathrm{p}$.

3. Ismakov R.A. et al. Zhidkost dlya glusheniya skvazhin [Killing fluid]. Patent 2260112 Russian Federation no.2004115031 (2005).

4. Labenski F., Reid P., Santos H. Drilling fluids approaches for control of wellbore instability in fractured formations. SPE/IADC Middle East Drilling Technology Conference and Exhibition. Abu Dhabi, 2003. DOI: 10.2118/85304-MS

5. Shishkov S.N. et al. Burovye rastvory na nevodnoy osnove. Problemy, perspektivy razvitiya i oblast primeneniya [Non-aqueous drilling fluids. Problems, development prospects and scope]. Burenie i neft, 2008, no.3, pp.26-29.

6. Shishkov S.N. et al. Emulsionnye burovye rastvory na nevodnoy osnove dlya kachestvennogo vskrytiya produktivnykh plastov s ANPD [Non-aqueous emulsion drilling muds for high-quality opening of productive formations with abnormally low formation pressure]. Tekhnika $i$ tekhnologiya zakanchivaniya $i$ remonta skvazhin $v$ usloviyakh anpd. Sbornik nauchnykh trudov OAO NPO "Burenie". Krasnodar, 2002, iss.8, pp.27-35.

7. Shishkov S.N. et al. Emulsionnye rastvory na uglevodorodnoy osnove i ikh ekologicheski maloopasnye modifikatsii [Hydrocarbon-based emulsion solutions and their environmentally hazardous modifications]. Importozameshchayushchie tekhnicheskie sredstva $i$ materialy. Sbornik nauchnykh trudov OAO NPO "Burenie". Krasnodar, 2003, iss.9, pp.13-26.

8. Zavorotnyy V.L. et al. Razrabotka i issledovanie retseptur emulsionnykh rastvorov na osnove mineralnykh masel [Development and research of mineral oil-base emulsive solutions compositions]. NTZh. Zashchita okruzhayushchey sredy v neftegazovom komplekse, 2010, no.1, pp.34-38.

9. Vishnyakov D.Ya. Ekonomicheskiy analiz metodov likvidatsii po-sledstviy avariynykh razlivov nefti [Economic analysis of oil spill response mitigation techniques]. Ekologiya i promyshlennost Rossii, 2005, no.6, pp. $42-45$

10. Zavorotnyy V.L. et al. Ekologicheskie aspekty primeneniya burovykh rastvorov na uglevodorodnoy osnove [Environmental aspects of the use of hydrocarbon-based drilling fluids]. Geoekologiya i sovremennaya geodinamika neftegazonosnykh regionov. Mezhdunarodnaya nauchnoprakticheskaya konferentsiya. Moscow, 2000.

11. Galyan D.A., Shvets T.S., Korneeva V.P. Ekologicheski chistye sostavy burovykh rastvorov na nevodnoy osnove [Environmentally friendly non-aqueous drilling fluid formulations]. NTZh. Zashchita okruzhayushchey sredy $v$ neftegazovom komplekse, 2006, no.6, pp.47-49

12. Shishkov S.N. et al. Ekologicheskie i tekhnologicheskie aspekty primeneniya emulsionnykh burovykh rastvorov na uglevodorodnoy osnove [Ecological and technological aspects of use of emulsion drilling fluids on a hydrocarbon basis]. Novye tekhnologii, tekhnicheskie sredstva i materialy $v$ oblasti promyvki pri burenii $i$ remonte neftyanykh $i$ gazovykh skvazhin. Sbornik nauchnykh trudov OAO NPO "Burenie". Krasnodar, 2001, iss.6, pp.29-40.

13. Shishkov S.N. et al. Issledovanie vliyaniya dispersionnoy sredy i PAV na solvatatsiyu tverdoy fazy i reologicheskie svoystva uglevodorodnykh suspenziy [Study of the influence of the dispersion medium and surfactant on the solvation of the solid phase and the rheological properties of hydrocarbon suspensions]. Servisnoe obespechenie bureniya $i$ remonta skvazhin. Sbornik nauchnykh trudov OAO NPO "Burenie". Krasnodar, 2004, iss.11, pp.80-93.

14. McKee J.D.A., Dowrick K., Astleford S.J. A new development towards improved synthetic based mud performance. Paper SPE-29405-MS presented at the SPE/IADC Drilling Conference, 28 February - 2 March. Amsterdam, 1998. DOI: $10.2118 / 29405-M S$

15. Yassin Abu Azam M., Kamis A. Palm oil derivative as a based fluid in formulating oil based drilling mud. Paper SPE-21167-MS presented at the SPE Latin America Petroleum Engineering Conference, 14-19 October. Rio de Janeiro, 1990. DOI: 10.2118/21167-MS

16. Fefelov Yu.V. et al. Burovye rastvory na nevodnoy osnove dlya bureniya skvazhin s bolshim prilozheniem [Nonwater based drilling fluids for drilling wells with large application]. NTZh. Geologiya, geofizika $i$ razrabotka neftyanykh i gazovykh mestorozhdeniy, 2007, no.9, pp.47-49. 
17. Tokunov V.I. et al. Gidrofobnaya emulsiya [Hydrophobic emulsion]. Patent 2263700 Russian Federation no.2004116854/03 (2005).

18. Primenenie novogo ekologicheski chistogo burovogo rastvora $\mathrm{v}$ akvatorii Severnogo morya [Use of new environmentally friendly drilling mud in the waters of the North Sea]. NTZh. Zashchita ot korrozii $i$ okhrana okruzhayushchey sredy, 1996, no.1, pp.25.

19. Aston M., Mihalik P., Tunbridge J., Clarke S. Towards zero fluid loss oil based muds. Paper SPE 77446 presented at the SPE Annual Technical Conference and Exhibition, 29 September - 2 October. San Antonio, 2002. DOI: $10.2118 / 77446-\mathrm{MS}$

20. Burovoy rastvor, sposobstvuyushchiy biodegradatsii bakteriy [Drilling mud that promotes biodegradation of bacteria]. NTZh. Zashchita ot korrozii i okhrana okruzhayushchey sredy, 1994, no.10, pp.33-34.

21. Dzhi Dzheffri S. Sposob polucheniya obrashchennogo burovogo rastvora, soderzhashchego smesi vtorichnykh slozhnykh efirov, poluchennykh $\mathrm{v}$ rezultate konversii olefinov [A method of obtaining a reversed drilling fluid containing mixtures of secondary esters obtained from the conversion of olefins]. Patent 2215017 Russian Federation no.2000120198/03 (2003).

22. Candler J.E., Rushing J.H., Leuterman A.J.J. Synthetic-based mud systems offer environmental benefits over traditional mud systems. Paper SPE-25993-MS presented at the SPE/EPA Exploration and Production Environmental Conference, 7-10 March. San Antonio, 1993. DOI: $10.2118 / 25993-M S$

23. Burrows K., Evans J., Hall J., Kirsner J. New low viscosity ester is suitable for drilling fluids in deepwater applications. Paper SPE- 66553-MS presented at the SPE/EPA/DOE Exploration and Production Environmental Conference, 26-28 February, San Antonio, 2001. DOI: $10.2118 / 66553-\mathrm{MS}$

24. van Oort E., Lee J., Friedheim J., Toups B. New flat-rheology synthetic-based mud for improved deepwater drilling. Paper SPE-90987-MS presented at the SPE Annual Technical Conference and Exhibition, 26-29 September. Houston, 2004. DOI: 10.2118/90987-MS

25. Myuller Kh., Kherold K.-P., Tapavitsa S. Reagent, uluchshayushchiy tekuchest invertnykh rastvorov [Reagent that improves the fluidity of invert solutions]. Patent 2013436 Russian Federation no.5001483/03 (1994).

26. Myuller $\mathrm{Kh}$. et al. Zhidkaya faza invertnogo burovogo rastvora tipa voda $\mathrm{v}$ masle dlya osvoeniya geologicheskikh mestorozhdeniy [Water-in-oil liquid phase invert mud for development of geological deposits]. Patent 2044025 Russian Federation no.4895872/03 (1995).

27. Saushin A.Z. et al. Gidrofobno-emulsionnye rastvory na osnove biologicheski aktivnoy dispersionnoy sredy [Hydrophobic emulsion solutions based on biologically active dispersion medium]. Oil industry, 2000, no.7, pp.16-18.
28. Fedoseev R.I., Koshelev V.N., Tatarinov A.V. Zagushchennoe kastorovoe maslo i emulsii na ego osnove novyy vid ekologicheski bezopasnykh burovykh rastvorov dlya morskogo bureniya [Thickened castor oil and emulsions based on it - a new kind of environmentally friendly drilling mud for offshore drilling]. Zakanchivanie $i$ remont skvazhin $v$ usloviyakh depressii na produktivnye plasty. Sbornik nauchnykh trudov OAO NPO "Burenie". Krasnodar, 2004, iss.12, pp.109-116.

29. Ihenacho P.C. et al. 50/50 oil-water ratio invert emulsion drilling mud using vegetable oil as continuous phase. Engineering and Technology International Journal of Chemical, Molecular, Nuclear, Materials and Metallurgical Engineering, 2016, vol.10, no.3, pp.256-259. DOI: 10.1999/1307-6892/10003725

30. ASTM standard son environmental site Characterization, 3rd ed., 2006, available at: https://www.astm.org/BOOKSTORE/COMPS/PDFS/SIT ECD06.pdf (accessed 06 March 2018).

31. Izuchenie biodegradatsii ispolzovannykh burovykh rastvorov, zagryaznyayushchikh vyburennuyu porodu [Study of the biodegradation of used drilling muds that pollute drilling]. NTZh. Zashchita ot korrozii i okhrana okruzhayushchey sredy, 1996, no.1, pp.25-26.

32. Ob utverzhdenii Kriteriev otneseniya otkhodov k I-V klassam opasnosti po stepeni negativnogo vozdeystviya na okruzhayushchuyu sredu [On approval of criteria for classification of waste to the I-V hazard classes according to the degree of negative impact on the environment]. Prikaz Minprirody Rossii ot 04.12.2014 no.536, available at: http://files.stroyinf.ru/Data2/1/ 4293757/4293757351.htm (accessed 06 March 2018).

33. Ojo O.A. Petroleum hydrocarbon utilization by native bacterial population from a waste water canal Southwest Nigeria. African Jornal of Biotechnology, 2006, vol.5 (4), pp.333-337.

34. Nilanjana D., Preethy C. Microbial degradation of petroleum hydrocarbon contaminants: an overview. Biotechnology Research International, 2011, pp.1-13. DOI: 10.4061/2011/941810

35. Wang Z.-Y. et al. Biodegradation of crude oil in contaminated soils by free and immobilized microorganisms. Pedosphere, 2012, vol.22, iss.5, pp.717-725. DOI: 10.1016/S1002-0160(12)60057-5

36. Van H., Singh A, Ward O.P. Physiological aspects. Part 1 in series of papers devoted to biosurfactants in microbiology and biotechnology. Biotechnology Advance, 2006, vol.24. pp.604-620. DOI: 10.1016/j.biotechadv.2006.08.001

37. Robbins J.A., Levy R. A review of the microbiological degradation of fuel. Directory of Microbicides for the Protection of Materials. Part One. 2nd ed. Springer Verlag, Berlin, 2004, pp.177-201. DOI: $10.1007 / 1-4020-2818-0 \_11$

38. Lee Y.C., Shin H.J., Ahn Y., Shin M.C., Lee M., Yang J.W. Biodegradation of diesel by mixed bacteria 
94 immobilized onto a hybrid support of peat moss and additives: A batch experiment. Journal of Hazardous Materials, 2010, vol.183, pp.940-944. DOI: 10.1016/j.jhazmat.2010.07.028

39. Issledovanie burovykh rastvorov, ispolzuemykh na morskikh mesto-rozhdeniyakh nefti, i tekhnologiy ikh udaleniya, snizhayushchikh vozdeystvie na morskuyu sredu sbrosov $\mathrm{v}$ more [Study of drilling muds used in offshore oil fields and technologies for their removal, reducing the impact on the marine environment of discharges into the sea], available at: file:///C:/Users/Dmitriy/Downloads/106_Doklad_Dzhonat ana_Uillsa_1.pdf (accessed 06 March 2018).

40. Targulyan O.Yu. Temnye stranitsy "chernogo zolota": Ekologicheskie aspekty deyatelnosti neftyanykh kompaniy v rossii [Dark pages of "black gold": Environmental aspects of the activities of oil companies in Russia]. Moscow, Sovet "Grinpis", 2002.

41. PND F 16.1:2:2.2:2.3:3.64-10. Metodika izmereniy massovoy doli nefteproduktov v probakh pochv, gruntov, donnykh otlozheniy, ilov, osadkov stochnykh vod, otkhodov proizvodstva i potrebleniya gravimetricheskim metodom, 2010 [Methods of measuring the mass fraction of petroleum products in samples of soil, ground, sediment, silt, sewage sludge, production and consumption waste by the gravimetric method], available: http://gostrf.com/normadata/ 1/4293807/4293807051.htm (accessed 06 March 2018).

42. Bazovye sinteticheskie masla IV gruppy. Polialfaolefiny (Synfluid PAO). "Tyazhelye" PAO
(Luvodur) [Base synthetic oils of the IV group. Polyalphaolefins (Synfluid PAO). "Heavy" PAO (Luvodur)], available at: http://fineximou.com/images/ user/4\%20-4gr.pdf (accessed 06 March 2018).

43. GOST 12.1.044-89 (ISO 4589-84). Sistema standartov bezopasnosti truda. Pozharovzryvoopasnost veshchestv i materialov. Nomenklatura pokazateley i metody ikh opredeleniya [Occupational safety standards system. Fire and explosion hazard of substances and materials. Nomenclature of indicators and methods for their determination]. Moscow, Standartinform, 2006, $100 \mathrm{p}$.

44. Glushchenko V.N., Orlov G.A., Silin M.A. Tekhnologicheskie protsessy vskrytiya plastov i dobychi nefti s ispolzovaniem obratnykh emulsiy [Technological processes of reservoir penetration and oil production using inverse emulsions]. Moscow, Interkontakt Nauka, 2008,360 p.

45. Proskuryakov V.A., Drabkin A.E. Khimiya nefti i gaza [Chemistry of oil and gas]. Saint Petersburg, Khimiya, 1995, $448 \mathrm{p}$.

46. Pravila bezopasnosti v neftyanoy i gazovoy promyshlennosti. Federalnye normy i pravila $\mathrm{v}$ oblasti promyshlennoy bezopasnosti [Safety rules in oil and gas industry. Federal rules and regulations in the field of industrial safety]. Moscow, Nauchno-tekhnicheskiy tsentr issledovaniy problem promyshlennoy bezopasnosti, 2013, seriya 08 , iss. $19,288 \mathrm{p}$.

47. Tokunov V.I., Kheyfets I.B. Gidrofobnoemulsionnye burovye rastvory [Hydrophobic emulsion drilling mud]. Moscow, Nedra, 1983, 167 p.

\section{Библиографический список}

1. Некрасова И.Л., Гаршина О.В., Хвощин П.А. Теория и практика использования инвертно-эмульсионных растворов в процессе строительства скважин: моногр. Пермь: Астер, 2016. - 148 с

2. Петров Н.А. Повышение качества заканчивания скважин с полимиктовыми коллекторами нефти: учеб. пособие. - Уфа: Уфимский гос. нефтяной техн. ун-т, 2010. -68 c.

3. Жидкость для глушения скважин: пат. 2260112 Рос. Федерация. № 2004115031 / Исмаков Р.А. и др.; заявл. 18.05.2004; опубл. 10.09.05, Бюл. № 25.

4. Labenski F., Reid P., Santos H. Drilling fluids approaches for control of wellbore instability in fractured formations // SPE/IADC Middle East Drilling Technology Conference and Exhibition, 20-22 October. - Abu Dhabi, 2003. DOI: $10.2118 / 85304-\mathrm{MS}$

5. Буровые растворы на неводной основе. Проблемы, перспективы развития и область применения / С.Н. Шишков [и др.] // Бурение и нефть. - 2008. № 3. - С. 26-29.

6. Эмульсионные буровые растворы на неводной основе для качественного вскрытия продуктивных пластов с АНПД / С.Н. Шишков [и др.] // Техника и технология заканчивания и ремонта скважин в условиях АНПД: сб. науч. тр. ОАО НПО «Бурение». Краснодар, 2002. - Вып. 8. - С. 27-35.

7. Эмульсионные растворы на углеводородной основе и их экологически малоопасные модификации / C.Н. Шишков [и др.] // Импортозамещающие технические средства и материалы: сб. науч. тр. ОАО НПО «Бурение». - Краснодар, 2003. - Вып. 9. C. 13-26.

8. Разработка и исследование рецептур эмульсионных растворов на основе минеральных масел / В.Л. Заворотный [и др.] // НТЖ. Защита окружающей среды в нефтегазовом комплексе. -2010. - № 1. - С. 34-38.

9. Вишняков Д.Я. Экономический анализ методов ликвидации последствий аварийных разливов нефти // Экология и промышленность России. - 2005. - № 6. C. $42-45$

10. Экологические аспекты применения буровых растворов на углеводородной основе / В.Л. Заворотный [и др.] // Геоэкология и современная геодинамика 
нефтегазоносных регионов: междунар. науч.-практ. конф. - М., 2000.

11. Галян Д.А., Швец Т.С., Корнеева В.П. Экологически чистые составы буровых растворов на неводной основе // НТЖ. Защита окружающей среды в нефтегазовом комплексе. - 2006. - № 6. С. $47-49$

12. Экологические и технологические аспекты применения эмульсионных буровых растворов на углеводородной основе / С.Н. Шишков [и др.] // Новые технологии, технические средства и материалы в области промывки при бурении и ремонте нефтяных и газовых скважин: сб. науч. тр. ОАО НПО «Бурение». Краснодар, 2001. - Вып. 6. - С. 29-40.

13. Исследование влияния дисперсионной среды и ПАВ на сольватацию твердой фазы и реологические свойства углеводородных суспензий / С.Н. Шишков [и др.] // Сервисное обеспечение бурения и ремонта скважин: сб. науч. тр. ОАО НПО «Бурение». Краснодар, 2004. - Вып. 11. - С. 80-93.

14. McKee J.D.A., Dowrick K., Astleford S.J. A new development towards improved synthetic based mud performance // Paper SPE-29405-MS presented at the SPE/IADC Drilling Conference, 28 February - 2 March. Amsterdam, 1998. DOI: 10.2118/29405-MS

15. Yassin Abu Azam M., Kamis A. Palm oil derivative as a based fluid in formulating oil based drilling mud // Paper SPE-21167-MS presented at the SPE Latin America Petroleum Engineering Conference, 14-19 October. - Rio de Janeiro, 1990. DOI: 10.2118/21167-MS

16. Буровые растворы на неводной основе для бурения скважин с большим приложением / Ю.В. Фефелов [и др.] // НТЖ. Геология, геофизика и разработка нефтяных и газовых месторождений. 2007. - № 9. - С. 47-49.

17. Гидрофобная эмульсия: пат. 2263700 Рос. Федерация № 2004116854/03 / Токунов В.И. и др.; заявл. 03.06.2004; опубл. 10.11.2005, Бюл. №31

18. Применение нового экологически чистого бурового раствора в акватории Северного моря // НТЖ. Защита от коррозии и охрана окружающей среды. - 1996. - № 1. - С. 25.

19. Towards zero fluid loss oil based muds / M. Aston, P. Mihalik, J. Tunbridge, S. Clarke // Paper SPE 77446 presented at the SPE Annual Technical Conference and Exhibition, 29 September -2 October. - San Antonio, 2002. DOI: $10.2118 / 77446-\mathrm{MS}$

20. Буровой раствор, способствующий биодеградации бактерий // НТЖ. Защита от коррозии и охрана окружающей среды. - 1994. - № 10. - С. 33-34.

21. Способ получения обращенного бурового раствора, содержащего смеси вторичных сложных эфиров, полученных в результате конверсии олефинов: пат. 2215017 Рос. Федерация № 2000120198/03 / Джи Джеффри С.; заявл. 09.12.1998; опубл. 27.10.2003, Бюл. № 30 (2 ч.).
22. Candler J.E., Rushing J.H., Leuterman A.J.J. Synthetic-based mud systems offer environmental benefits over traditional mud systems // Paper SPE-25993-MS presented at the SPE/EPA Exploration and Production Environmental Conference, 7-10 March. - San Antonio, 1993. DOI: $10.2118 / 25993-\mathrm{MS}$

23. New low viscosity ester is suitable for drilling fluids in deepwater applications / K. Burrows, J. Evans, J. Hall, J. Kirsner // Paper SPE- 66553-MS presented at the SPE/EPA/DOE Exploration and Production Environmental Conference, 26-28 February. - San Antonio, 2001. DOI: 10.2118/66553-MS

24. New flat-rheology synthetic-based mud for improved deepwater drilling / E. van Oort, J. Lee, J. Friedheim, B. Toups // Paper SPE-90987-MS presented at the SPE Annual Technical Conference and Exhibition, 26-29 September. - Houston, 2004. DOI: $10.2118 / 90987-\mathrm{MS}$

25. Реагент, улучшающий текучесть инвертных растворов: пат. 2013436 Рос. Федерация № 5001483/03 / Мюллер Х., Херольд К.-П., Тапавица С.; заявл. 08.08.1991; опубл. 30.05.1994, Бюл. № 10.

26. Жидкая фаза инвертного бурового раствора типа вода в масле для освоения геологических месторождений: пат. 2044025 Рос. Федерация, № 4895872/03 / Мюллер Х. [и др.]; заявл. 17.06.1991; опубл. 20.09.1995, Бюл. № 26.

27. Гидрофобно-эмульсионные растворы на основе биологически активной дисперсионной среды / А.3. Саушин [и др.] // Нефтяное хозяйство. - 2000. № 7. - С. 16-18.

28. Федосеев Р.И., Кошелев В.Н., Татаринов А.В. Загущенное касторовое масло и эмульсии на его основе - новый вид экологически безопасных буровых растворов для морского бурения // Заканчивание и ремонт скважин в условиях депрессии на продуктивные пласты: сб. науч. тр. ОАО НПО «Бурение». Краснодар, 2004 - Вып. 12. - С. 109-116.

29. 50/50 oil-water ratio invert emulsion drilling mud using vegetable oil as continuous phase / P.C. Ihenacho [et al.] // World Academy of Science, Engineering and Technology International Journal of Chemical, Molecular, Nuclear, Materials and Metallurgical Engineering. - 2016. - Vol. 10, № 3. - P. 256-259. DOI: 10.1999/1307-6892/10003725

30. ASTM Standard son environmental site characterization [Электронный pecypc]. - 3rd ed. - 2006. URL: https://www.astm.org/BOOKSTORE/COMPS/PDFS/ SITECD06.pdf (дата обращения: 06.03.2018).

31. Изучение биодеградации использованных буровых растворов, загрязняющих выбуренную породу // НТЖ. Защита от коррозии и охрана окружающей среды. - 1996. - № 1. - С. 25-26.

32. Об утверждении Критериев отнесения отходов к I-V классам опасности по степени негативного воздействия на окружающую среду: приказ Минприроды 
России от 04.12.2014 № 536 [Электронный ресурс]. URL: http://files.stroyinf.ru/Data2/1/4293757/4293757351.htm (дата обращения: 06.03.2018).

33. Ojo O.A. Petroleum hydrocarbon utilization by native bacterial population from a waste water canal Southwest Nigeria // African Jornal of Biotechnology. 2006. - Vol. 5 (4). - P. 333-337.

34. Nilanjana D., Preethy C. Microbial degradation of petroleum hydrocarbon contaminants: an overview // Biotechnology Research International. - 2011. - P. 1-13. DOI: $10.4061 / 2011 / 941810$

35. Biodegradation of crude oil in contaminated soils by free and immobilized microorganisms / Z.-Y. Wang [et al.] // Pedosphere. - 2012. - Vol. 22, iss. 5. P. 717-725. DOI: 10.1016/S1002-0160(12)60057-5

36. Van H., Singh A, Ward O.P. Physiological aspects. Part 1 in series of papers devoted to biosurfactants in microbiology and biotechnology // Biotechnology Advance. - 2006. - Vol. 24. - P. 604-620. DOI: 10.1016/j.biotechadv.2006.08.001

37. Robbins J.A., Levy R. A review of the microbiological degradation of fuel // Directory of Microbicides for the Protection of Materials. Part One. 2nd ed. - Springer Verlag, Berlin, 2004. - P. 177-201. DOI: $10.1007 / 1-4020-2818-0 \_11$

38. Biodegradation of diesel by mixed bacteria 94 immobilized onto a hybrid support of peat moss and additives: A batch experiment / Y.C. Lee, H.J. Shin, Y. Ahn, M.C. Shin, M. Lee, J.W. Yang // Journal of Hazardous Materials. - 2010. - Vol. 183. - P. 940-944. DOI: 10.1016/j.jhazmat.2010.07.028

39. Исследование буровых растворов, используемых на морских месторождениях нефти, и технологий их удаления, снижающих воздействие на морскую среду сбросов в море [Электронный ресурс].
URL: file://C:/Users/Dmitriy/Downloads/106_Doklad_Dzhonatana_Uillsa_1.pdf (дата обращения: 06.03.2018).

40. Таргулян О.Ю. Темные страницы «черного золота»: экологические аспекты деятельности нефтяных компаний в России. - М.: Совет «Гринпис», 2002.

41. ПНД $Ф \quad$ 16.1:2:2.2:2.3:3.64-10. Методика измерений массовой доли нефтепродуктов в пробах почв, грунтов, донных отложений, илов, осадков сточных вод, отходов производства и потребления гравиметрическим методом. 2010. [Электронный pecypc]. - URL: http:/gostrf.com/normadata/ 1/4293807/ 4293807051.htm (дата обращения: 06.03.2018).

42. Базовые синтетические масла IV группы. Полиальфаолефины (Synfluid PAO). «Тяжелые» PAO (Luvodur) [Электронный peсурс]. URL: http://fineximou.com/images/user/4\%20-4gr.pdf (дата обращения: 06.03.2018).

43. ГОСТ 12.1.044-89 (ИСО 4589-84). Система стандартов безопасности труда. Пожаровзрывоопасность веществ и материалов. Номенклатура показателей и методы их определения. - М.: Стандартинформ, 2006. - $100 \mathrm{c}$

44. Глущенко В.Н., Орлов Г.А., Силин М.А. Технологические процессы вскрытия пластов и добычи нефти с использованием обратных эмульсий. М.: Интерконтакт Наука, 2008. - 360 с.

45. Проскуряков В.А., Драбкин А.Е. Химия нефти и газа. - СПб.: Химия, 1995. - 448 с

46. Правила безопасности в нефтяной и газовой промышленности: Федеральные нормы и правила в области промышленной безопасности. - М.: Научнотехнический центр исследований проблем промышленной безопасности, 2013. - Сер. 08, вып. 19. - 288 с.

47. Токунов В.И. Хейфец И.Б. Гидрофобноэмульсионные буровые растворы. - М.: Недра, 1983. - 167 с.

Please cite this article in English as:

Nekrasova I.L. Aspects of environmental and industrial safety of non-aqueous process fluids in construction and completion of wells. Perm Journal of Petroleum and Mining Engineering, 2018, vol.18, no.1, pp.41-52. DOI: 10.15593/2224-9923/2018.3.4

Просьба ссылаться на эту статью в русскоязычных источниках следующим образом:

Некрасова И.Л. Аспекты экологической и промышленной безопасности применения технологических жидкостей на неводной основе в процессах строительства и освоения скважин // Вестник Пермского национального исследовательского политехнического университета. Геология. Нефтегазовое и горное дело. - 2018. - Т.18, №1. - C.41-52. DOI: 10.15593/2224-9923/2018.3.4 